\title{
The Importance of Making Use of a Syllabus of the Oral Skill in Teaching and in Teacher Training: \\ The Case of Oral Expression Teachers at the Department of Letters and English Language, University of Constantine
}

\begin{abstract}
:
The current paper investigates the teaching ofOral Expression at the Department of Letters and English Language. It aims to find out whether there is a specific method or methodsused to teach this module and whether the teachers are provided with a syllabus to follow. Lack of a precise method and a syllabus leads to inconsistency and incoherence in teaching which are reflected in heterogeneousstudent levels of progress. It also examines the teachers' awareness and knowledge of the different existing foreign language teaching methods and approaches, which tests the effectiveness and the reliability of their teaching practices. Finally, this paper addresses the importance of teacher training to enhance the teachers' performance, raise their awareness of the teaching and learning processes, of how to implement a syllabus and how to remain up-to date with the latest teaching techniques and strategies.

Key Words: Oral Expression, EFL Teaching Methods, Syllabus, Teacher Training.
\end{abstract}

يلقي هذا المقال الضوء على تدريس وحدة التعبير الثفهي و مهار ات التهي

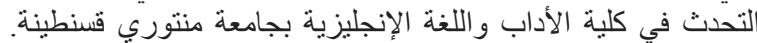

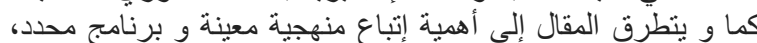

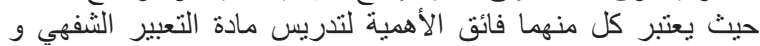

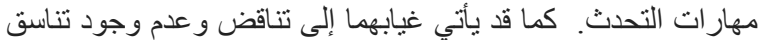

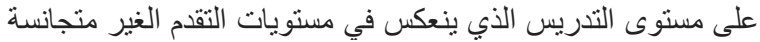

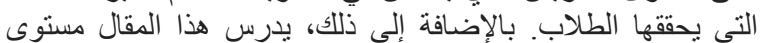

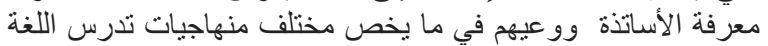

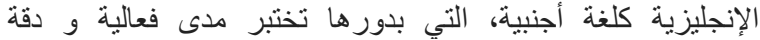

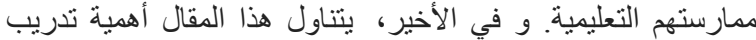

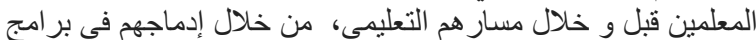

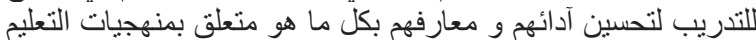
وكيفية تنفيذ البر امج المخصصة للتدريس.

\author{
Amina Haddid \\ Faculty of Letters and Languages \\ Department of Foreign Languages \\ University of Mentouri \\ Constantine
}

\section{Introduction :}

Teaching the oral skill requires a lot of efforts, and it is the focal interest and the main goal of most English language learners. According to Richards (2008) "[...] learners evaluate the success in language learning as well as the effectiveness of their English course on the basis of how much they feel they have improved in their spoken language proficiency" (9). 
For this reason, teaching the subject of Oral Expression at the Department of Letters and English Language has always been a challenge for its teachers, especially that no clear and consistent syllabus is available which makes their tasks difficult. Each teacher has to come up with his own lessons to teach this module throughout the year. Furthermore, no clear-cut method is implemented. Incoherent teaching techniques and strategies vary from one teacher to another. New teachers and even experienced ones have never received any type of teacher training (pre-service and in-service) at the Department of Letters and English Language, which calls for a need to provide such programs to improve their knowledge about the teaching methods and syllabusesand about how each should be applied in accordance with the context and students' needs.

\section{Literature Review}

English Language teaching methods constituteone of the areas that have received a lot of attention in the past few years. Researchers, pedagogues, and teachers (For example Richards1990, Nunan 1991)have been searching for the appropriate methods to teach English in variouscontexts, and which help learners master the language and become both communicatively and grammatically competent. Richards and Rodgers(1986) state that:

The proliferation of approaches and methods is a prominent characteristic of contemporary second language, and foreign language teaching. To some, this reflects strength of our profession. Invention of new classroom practices and approaches to designing language programs and materials reflects a commitment to finding more efficient and more effective ways of teaching languages (iv).

The environment and the needs of the learners differ from one country to another and from one school to another. Many scholars, such as Richards (2008) and Larsen-Freeman (2000), consider EFL teaching as a dynamic process. According to Sierra(1995) "To consider FLT as a process means that teaching is not static but changing to respond to new needs and demands, as teachers, applied linguists and educationalist can prove" (110). Teachers need to tailor their teaching according to the environment and the needs of their learners. From this, we can understand that one teaching method might not suit all contexts, and probably more than one should be used to meet the various needs and fit in different contexts. According to Richards and Rodgers (1986) "The classroom teacher and the program coordinator have a wider variety of methodological options to choose from than ever before. They can choose methods and materials according to the needs of the learners, preferences of teachers, and constraints of school or educational setting" (vii).

Teachers are required to have a solid background about EFL teaching methods and the various techniques and strategies to guarantee better results both at the teaching proficiency level and at the learners' learning level. This 
knowledge also helps teachers as decision makers and syllabus designers to make sensible decisions about what to include in a well-structured syllabus, and about the method to be applied according to what they consider suitable to the context and to the students' needs.

\section{Oral Skill in EFL Teaching Methods}

There have been many methods for teaching the various language skills with different degrees of emphasis on the oral skill. It would be enough to mention only the major ones.

\section{Grammar Translation Method}

This method first appeared in the $19^{\text {th }}$ century;it was adopted in both ESL and EFL contexts. It emphasizes the mastery of grammatical structures of the target language. This implies that this method somehow neglects the speaking skill; it stresses that the learners should be trained to understand grammatical structures and translation. Rogova (1983) states that in the Grammar Translation Method (GTM)" The book is the essential teaching aid. The assumption is that proficiency in the language can be acquired by learning a set of grammatical rules, to which the language is supposed to conform, and that by mechanically applying these rules, speed and fluency will grow with the use of the language. Primary objectives are the mastery of the graphic skills ,i.e., reading and writing, with secondary attention to hearing and speaking, translating and the working out of various exercises which require the application of grammar rules to selected data" (12).

\section{Direct Method}

According to Rogova (1983), the Direct Method came as a response to the Grammar-Translation Method. The main goal of teaching the foreign language shifted to the mastery of communication skills. People needed the language to communicate with foreigners as a result of the development of industry and international trade and colonial expansion. It is called 'direct' because unlike the Grammar Translation Method, it eliminates the use of the learners' mother tongue to explain utterances. Instead, it tries to connect the utterancein the foreign language 'directly' to the concept it denotes (12-14). Thus, GTM no longer served the needs of the foreign language learners; that is why it was neglected and replaced by a more beneficial and practical one which is the Direct Method. It is then obvious that the principles of the Direct Method contradict those of GTM.

\section{Audio-lingual Method}

Richard and Rodgers (1986) state that the term Audiolingualism "was coined by professor Nelson Brooks in 1964 (who) claimed to have transformed language teaching from an art to science, which would enable learners to achieve mastery of a foreign language effectively and efficiently" (48). It is similar to the direct method as they are both oral-based. But, unlike the direct method, the audio-lingual method is based on drilling grammatical sentence 
patterns, instead of focusing on vocabulary by exposing learners to its use in situations in order to acquire it (Larsen-Freeman, 2000, p. 35).

It is called Audio-lingual because it aims at the development of both listening and speaking skills. Speaking is primary in foreign language learning while writing is secondary, because language is a system of sounds used for social communication, and children acquire spoken language before the written one. Developing reading and writing skills could be the sole goal of learners, but before that they should not skip a significant stage where they develop their speaking and listening skills for a better mastery of the foreign language (Rogova, 1983, p. 21).

\section{Communicative Language Teaching}

In the mid 1960's, the Audio-lingual Method was discarded in the United States of America because it focused on the linguistic aspects of the language rather than the functional ones. Also, Situational Language Teaching used to be the dominant approach to teaching English in Britain, but it started to fade away in the late 1960's, due to the changes brought by the British Applied Linguists to the educational system as they started questioning the effectiveness of its theories. The British applied linguists Howatt, Candlin and Widdowson focused on the functional and the communicative potentials of the language which received scant attention in the different teaching approaches which existed at that time. A new approach known as the Communicative Approach to Teaching emerged (Richards and Rodgers, 1986, p. 64).

So, the focus of ELT has shifted towards a more practical perspective of the language, rather than a theoretical one. The structure of the language was not completely neglected, but it was given a secondary place because learning a language is knowing how to use it. Richard and Rodgers (1986) point out that CLT has two major goals "(a) make communicative competence the goal of language and (b) develop procedures for the teaching of the four language skills that acknowledge the interdependence of language and communication" (66). According to Candlin (2001), the Communicative Approach is considered as a cover term for a variety of classroom practices; its main goal is the learners' acquisition of the communicative competence and the main focus of the theories underlying this approach is language use in real life communication situations (155).

\section{Syllabus in EFL Teaching}

For teaching practice to be organized, unified and efficient, a well outlined syllabus is needed to be at the teachers' disposal. The term 'syllabus', in Britain, is related to the 'British institution of external examinations' which refers to the selection of given topics or the course content that both teachers and learners use as a reference to get ready for a particular examination. However, in North America the terms 'course study', 'curriculum' and 
'program' basically share the same basics (Stern, 1984, p.5). Widdowson (1984) defines syllabus as "a framework within which activities can be carried with a teaching device to facilitate learning" (qtd.in Nunan, 2000, p.6). So, syllabus is a reference or an outline that specifies the type of classroom activities, the materials and strategies with which those practices should be introduced in order to meet the learning needs and help make the teaching and the learning process more organized and coherent.

There are those who think that a syllabus is concerned with both content and methodology such as Yalden (1984) and Candlin (2001), while others believe that it is restricted to the specification and the assessment of the course content such as Nunan (2000) and Widdowson (1984). For instance, according to Brumfit (1984), a syllabus "generates a set of units of work, and implies particular methodologies; indeed methodology can be considered part of the syllabus specification" (3).

A syllabus serves as a basis for the teaching and learning processes, but the latter is influenced by other compulsory factors such as the teaching approaches, activities, materials, teacher-learner classroom interaction. Language teaching and learning are informed by students' needs analysis (Finney, 2002, p. 76).

For an effective implementation of a syllabus, teachers need to be trained. Finney (2002) asserts that teachers are to be trained continuously throughout their career. Teachers need to have three main characteristics: They need to be 'analytical, reflective, and creative'. They are also expected to have enough knowledge about the various teaching approaches, to be willing to use a wide range of materials, to be up dated with the new teaching methods and ideas and to be eager to adopt them. The essence of teacher training must be the development of researchers; these are teachers who are always innovative and productive, continuously researching in their field and not only presenting what is in the syllabus passively (77).

\section{Teacher Training}

The absence of teacher training may hinder the implementation of an effective syllabus and thesuccess of the teaching methods and approaches. Savignon (1983) states that the quality of the instructor determines the efficiency of any syllabus; that is why it is critical to give great importance to the in-service training of the instructors (34). Richards and Schmidt (2002) define teacher education as "the field of study that deals with the preparation and professional development of teachers". And they continue to make a distinction between teacher training and teacher development. The former is designed for beginner teachers, and it has to do with the fundamental skills and techniques of teaching, such as lesson planning, error correction, methods to teach the four language skills and so on. Teachers receive such training in $a$ pre-service education programme. Teacher development refers to the post- 
The Importance of Making Use of a Syllabus of the Oral Skill in Teaching and in

initial teacher training which focuses on the continuing development of teachers in the teaching profession and the development of particular skills. They receive such training in an in-service education programmedealing with teachers' self-assessmentand the analysis of their teaching method (542).

\section{Data Collection}

The current paper investigates teachers of Oral Expression teaching second year students at the Department of Letters and English Language. Teachers' questionnaire and classroom observation are the two main tools.

\section{1- Classroom Observation}

The classroom observation took two years of attending Oral Expression classeswith five different teachers. The observation was conducted during the second semester of the academic year 2014-2015, and the first semester of the academic year 2015-2016. During the second semester of the first year, the programme was mainly about assignments freely chosen, prepared and presented by the students. The only difference observed was at the level of the teachers' roles. They were asked in the post-observation interview about whether they pre-taught presentation skills to their students, and they all answered 'No',except one who mentioned discussing them briefly with the learners and onewho answered that hetaught phonetic transcription and pronunciation. In the first semester, it was observed that there was no consistency in the topics covered by the five different teachers. Each one of them had his own method and discussed completely different sets of topics and introduced different ranges of lessons. This was confirmed by the end of the class, when teachers were asked whether they were provided with a syllabus to teach the module, and they all answered negatively. They were also requested to list the ten first lessons they introduce in the first semester to teach second year students, and their answers showed no coherence which also proved that there is no unity or homogeneity at the level of lessons, and no coordination among teachers of Oral Expression at the department of Letters and English Language exists.

\section{2- Questionnaire}

\begin{tabular}{|l|l|c|c|c|c|}
\hline Number & Questions & Yes & No & $\begin{array}{c}\text { No } \\
\text { answer }\end{array}$ & Total \\
\hline
\end{tabular}




\begin{tabular}{|c|l|l|l|l|l|}
\hline 1 & $\begin{array}{l}\text { As an EFL teacher, have you } \\
\text { received any training in } \\
\text { ELT? }\end{array}$ & $12.5 \%$ & $87.5 \%$ & $0 \%$ & $100 \%$ \\
\hline 2 & $\begin{array}{l}\text { Are you given any } \\
\text { opportunities be trained at } \\
\text { the Department of English? }\end{array}$ & $12.5 \%$ & $81.25 \%$ & $6.25 \%$ & $100 \%$ \\
\hline 3 & $\begin{array}{l}\text { Do teachers need to be } \\
\text { trained before and even } \\
\text { during their teaching career? }\end{array}$ & $100 \%$ & $0 \%$ & $0 \%$ & $100 \%$ \\
\hline
\end{tabular}

The population of the questionnaire consisted of 20 teachers of Oral Expression who were requested to fill out a questionnaire. Only 16 of them answered. The analysis of the questions showed the following results:

Table 1: Teacher Training

These results reveal that teachers at the Department of Letters and English Language are

not provided with teacher training and teacher development programs, although they all see the crucial need for that to enhance their knowledge about teaching and learning processes and to improve their teaching practice. Only two teachers stated that they were trained, but when asked where and for how long, one of them referred to the module of TEFL she studied at the university, and the other one mentioned that she studied at the Ecole Normale Supérieure 'ENS' teacher training school. These are not the training programmes which are the concern of this paper.

\begin{tabular}{|c|l|c|c|c|c|}
\hline Number & \multicolumn{1}{|c|}{ Questions } & Yes & No & $\begin{array}{c}\text { No } \\
\text { answer }\end{array}$ & Total \\
\hline 1 & $\begin{array}{l}\text { Are you bound by a specific } \\
\text { method at the department of } \\
\text { English? }\end{array}$ & $\mathbf{0 \%}$ & $\mathbf{1 0 0 \%}$ & $\mathbf{0 \%}$ & $\mathbf{1 0 0 \%}$ \\
\hline 2 & $\begin{array}{l}\text { Are you provided by a specific } \\
\text { syllabus to teach Oral } \\
\text { Expression? }\end{array}$ & $\mathbf{0 \%}$ & $\mathbf{1 0 0 \%}$ & $\mathbf{0 \%}$ & $\mathbf{1 0 0 \%}$ \\
\hline
\end{tabular}

Table 2: Teaching Methods and Syllabus

The aim behind these two questions is to have a clear idea aboutthe availability of a syllabus and the existence of particular method (s) to teach Oral Expression at the Department of Letters and English Language. The answers proved that there is no syllabus, and teaching methods are used randomly and differ from one teacher to another. And when asked to describe 
The Importance of Making Use of a Syllabus of the Oral Skill in Teaching and in Teacher Training: The Case of Oral Expression Teachers at the Department of Letters and English Language, University of Constantine

the methods used to teach this module, all 16 teachers answered differently showing no consistency, and 6 of them mentioned that they are not familiar with the concept of method and only teach the way they were once taught as students.A set of principles underlying each major method of teaching was listed and the teachers had to find out to which each principle belongs. The answers came as follows:

\begin{tabular}{|c|c|c|c|c|c|}
\hline Number & Questions & $\begin{array}{c}\text { Right } \\
\text { answer }\end{array}$ & $\begin{array}{l}\text { Wrong } \\
\text { Answer }\end{array}$ & $\begin{array}{c}\text { No } \\
\text { answer }\end{array}$ & Total \\
\hline 1 & $\begin{array}{l}\text { Oral language comes } \\
\text { before written language. }\end{array}$ & $0 \%$ & $100 \%$ & $0 \%$ & $100 \%$ \\
\hline 2 & $\begin{array}{l}\text { The teacher is the model; } \\
\text { he creates the situation and } \\
\text { teaches through } \\
\text { questioning and eliciting } \\
\text { the learners' answer. }\end{array}$ & $25 \%$ & $68.75 \%$ & $6.25 \%$ & $100 \%$ \\
\hline 3 & Use of L1 is forbidden. & $18.75 \%$ & $81.25 \%$ & $0 \%$ & $100 \%$ \\
\hline 4 & $\begin{array}{l}\text { Students are expected to } \\
\text { interact with the language } \\
\text { system. }\end{array}$ & $12.5 \%$ & $75 \%$ & $12.5 \%$ & $100 \%$ \\
\hline 5 & $\begin{array}{l}\text { Teachers play an } \\
\text { authoritarian role in the } \\
\text { classroom and the } \\
\text { predominant interaction is } \\
\text { between teacher-student. }\end{array}$ & $6.25 \%$ & $81.25 \%$ & $12.5 \%$ & $100 \%$ \\
\hline 6 & $\begin{array}{l}\text { Language learning is a } \\
\text { habit formation. }\end{array}$ & $25 \%$ & $62.5 \%$ & $12.5 \%$ & $100 \%$ \\
\hline 7 & $\begin{array}{l}\text { Students are expected to } \\
\text { deduce word meaning } \\
\text { from context without } \\
\text { translations or explanations } \\
\text { in the mother tongue. }\end{array}$ & $0 \%$ & $87.5 \%$ & $12.5 \%$ & $100 \%$ \\
\hline 8 & $\begin{array}{l}\text { The basic teaching unit is } \\
\text { the sentence }\end{array}$ & $12.5 \%$ & $68.75 \%$ & $18.75 \%$ & $100 \%$ \\
\hline
\end{tabular}

\section{Methods}

Table 3: Teachers' Knowledge of Teaching

As the above table shows, the absolute majority of teachers could not match the principles with their methods/ approaches. This proves that there is a lack of knowledge and awareness ofthe teaching methods which again calls for the need of teacher training and development.

\section{Conclusion}


The results of the present study point to one conclusion: teaching Oral Expression at the Department of Letters and English Language is random and inhomogeneous, in the sense that, teachers introduce completely different lessons and use different methods to teach this module which is due to the absence of a syllabus, and the lack of coordination between teachers. Moreover, it should be admitted that lack of knowledge of the teaching methods and approaches has a great effect on the teachers' decisions on what to teach and how it should be taught taking also into consideration some other factors such as the students' needs, the environment...etc., and to reach this level of awareness, teachers need to be well informed. However, according to the results, teachers confuse and sometimes do not even know what methods and approaches this teaching entails. Teacher training is the remedy for such misconceptions about language teaching approaches and methods, and is also a source of preparation and development of teachers. Also, the influence of teacher training and development on teachers' practice and productivity is obvious. All teachers see the implementation of such programs at the Department of Letters and English Language as an urgent and a crucial need. The collected data reveal that teachers do need teacher training to develop their teaching skills and frame their ideas about what teaching involves. This knowledge also helps them be more flexible and analytical when implementing a specific syllabus when deciding on how each element has to be introduced, what should be included, added or omitted.

\section{References}

Brumfit, C. J. "Introduction." General English Syllabus Design. Ed. C.J. Brumfit, Pergamon Press, 1984, pp. 1-4.

Candlin N., Christopher, Neil Mercer, editors. English Language Teaching in its Social Context.Routledge,2001.

Finney, D. "The ELT Curriculum: A Flexible Model for a Changing World." Methodology in Language Teaching. Ed. J. C. Richards and Willy A. Renandya, Cambridge UP, 2002, pp. 69-77.

Larsen-freeman, Dian. Techniques and Principles in Language Teaching. Oxford, 2000.

Nunan, David. Language Teaching Methodology. Hong Kong UP, 2000.

Richards, J.C. Teaching Listening and Speaking: From Theory to Practice. Cambridge UP, 2008.

Richards, J. C., and Richard Schmidt. Longman Dictionary of Language Teaching and Applied Linguistics, Pearson Education, 2002.

Richards, J.C, and T.S. Rodgers. Approaches and Methods in Language Teaching.Cambridge UP, 1986

Rogova, G. V. Methods of Teaching English.Prosveshchenie, 1983. 
The Importance of Making Use of a Syllabus of the Oral Skill in Teaching and in

Teacher Training: The Case of Oral Expression Teachers at the Department of Letters and English Language, University of Constantine

Savignon, Sandra J. "Communicative Language Teaching: Linguistic Theory and Classroom Practice." Interpreting Communicative Language teaching. Ed. Sandra J. Savignon, Yale UP,2002, pp. 1-28.

Sierra, F.C. "Foreign Language Teaching Methods: Some Issues and New Moves." $\quad$ Encuentrojournal 8,(1995), pp. 110-111.

Stern, H. H. "Review and Discussion." General English Syllabus Design. Ed. C.J. Brumfit, Pergamon Press, 1984, pp. 5-12.

\section{Appendix 1 Teachers' Questionnaire}

\section{Appendices}

1. As an EFL teacher, have you received any training in ELT?

Yes

No

2. Are you given any opportunities to be trained at the Department of English?

Yes

No

3. Do teachers need to be trained before and even during their teaching career?

Yes

No

4. Are you bound by a specific method at the department of English?

Yes

No

5. Are you provided by a specific syllabus to teach Oral Expression? Yes No

6. Which of the following features belongs to which teaching method or approach? (ST: Structural, GTM: Grammar Translation Method, Audio: Audio-lingual, CLT: Communicative Language Teaching)

- $\quad$ Oral language comes before written language.

$$
\text { ST GTM Audio CLT }
$$

- $\quad$ The teacher is the model; he creates the situation and teaches through questioning and eliciting the learners' answers.
ST
GTM
Audio
CLT

- $\quad$ Use of L1 is forbidden.

ST GTM Audio CLT

- $\quad$ Students are expected to interact with the language system.

ST GTM Audio CLT

- $\quad$ Teachers play an authoritarian role in the classroom and the predominant interaction is between teacher-student 


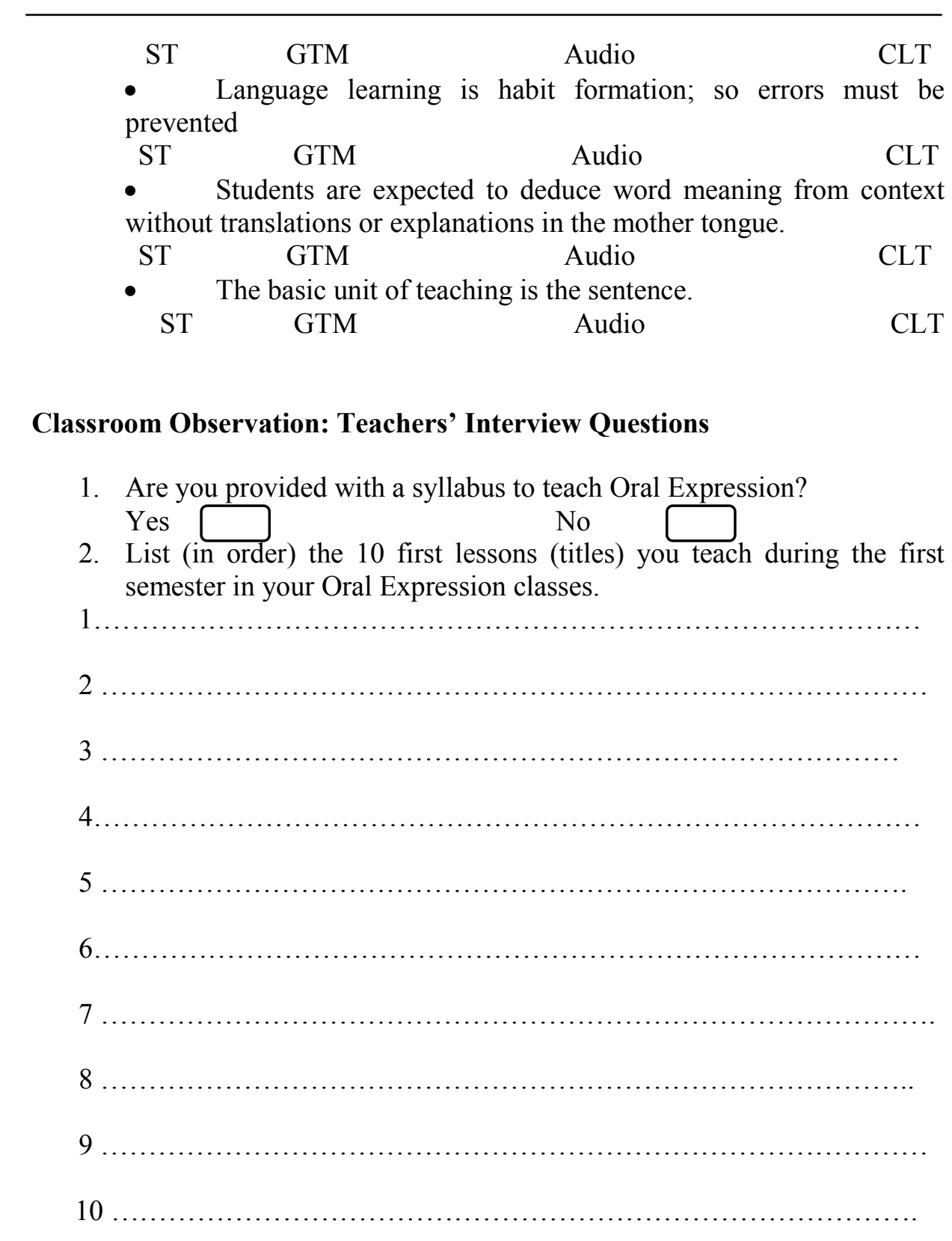

